\title{
Effect of Peanut Oil on Hair Texture Improvement
}

Ju-Sub Kim

Department of Beauty Design, Sangji University, Wonju-si, Gangwon-do, Korea

Corresponding author: Ju-Sub Kim, Department of Beauty Design, Sangji University, 84 Sangjidae-gil, Wonju-si, Gangwondo 26339, Korea

Tel.: +82 337300811

Fax: +82337300811

Email: c-miro@hanmail.net

Received June 29, 2020

Revised July 13, 2020

Accepted July 21, 2020

Published September 30, 2020

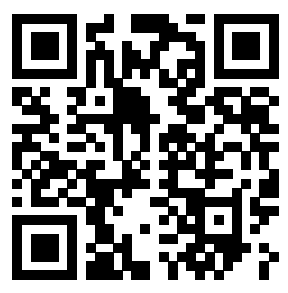

\begin{abstract}
Purpose: This study aimed to understand the effect of peanut oil on hair texture improvement. A hair texture improvement agent with peanut oil was produced and applied to damaged hair. Methods: The hair texture improvement agent was produced in different concentrations of peanut oil like $0 \%, 6 \%, 9 \%$, and $12 \%$. It was then applied to a bleached sample hair, heated, and left in natural condition. To quantify changes in surface color, the values of $\mathrm{L}^{*}, \mathrm{a}^{*}, \mathrm{~b}^{*}$, and $\Delta \mathrm{E}^{*}$ and the degree of fading were measured using a color difference scale. Also, the effect on hair texture was examined by measuring dye absorbance and luster using a tensile strength and methylene blue. Results: The $\mathrm{L}^{*}$ value of experimental group in level 7 decreased when the content of peanut oil increased. The change in $a^{*}$ and $b^{*}$ values was not significant. The increase of $\Delta \mathrm{E}^{*}$ value was also nonsignificant. The experimental group in level 9 showed no fading on the second day. It also showed an increase in tensile strength in level 7 compared to the control group. Further, the experimental group showed a decrease in absorbing methylene blue in level 7 compared to control group. Finally, the experimental group showed a luster increase in level 7 compared to the control group. Conclusions: The peanut oil had a significant effect on improving damaged hair texture. And further studies using various methods to measure the effects of peanut oil on hair texture are need.
\end{abstract}

Keywords: Peanut oil, Hair, Improvement, Hair texture, Damage

\section{Introduction}

아름다운 머리결을 유지하기 위해 헤어컨디셔너, 트리트먼트제 등을 모발에 도포하거나, 미용실에서 모발관리를 받기도 한다. 염 색이나 퍼머넌트를 하지 않은 모발은 대게 큰 모발의 손상이 없으며 건강한 모발의 범주에 해당한다. 모발의 손상 원인은 다양하나 특 히 화학적인 원인으로 염모제 도포 시 염모제 1제의 암모니아, 2제 의 과산화수소수에 의해 손상이 되며(Kim, 2017), 퍼머넌트 웨이브 1 제의 화학적인 성분 인 치오클리콜산 등에 의해 모발의 손상(Kim et al., 2013)이 일어난다. 이렇게 모발 손상이 일어나면 모발의 모 표피가 일어나거나 박리가 된다(Kim, 2006; Park et al., 2011). 헤 어컬러링에 의한 모발의 다양한 컬러 변화와 퍼머넌트에 의한 아름 다운 웨이브를 디자인하기 위해서는 모발의 손상이 동시에 오는 것 을 피할 수는 없다. 이러한 손상된 모발을 관리하기 위해 모표피, 모 피질에서 유실된 성분을 대체할 성분으로 실리콘 및 실리콘 유도체, PPT류(Kim et al., 2017) 등을 모발에 도포 해 모발 관리를 하고 있
다. 이러한 합성 성분뿐만 아니라 천연 성분을 함유한 트리먼트제 를 개발 연구하여 모발 관리에 사용하기도 한다. 모발의 손상을 방 지하거나, 모발 손상의 개선을 위한 연구는 시어버트를 이용한 헤어 트리트먼트의 모발 보호 효과에 관한 연구(Choi \& Jin, 2019), 창포 추출 액을 이용한 모발의 트리트먼트 효과(Kim \& Baek, 2008), 발 효 녹차를 이용한 모발의 트리트먼트 효과(Park \& Lim, 2014), 퍼 머넌트 웨이브 시술 시 황칠나무 잎 트리트먼트가 모발에 미치는 영 향(Ji, 2015) 등 천연성분으로 모발의 손상을 줄일 수 있는 방법, 원 료에 대한 연구가 이어지고 있다. 또한 오일 류를 주제로 한 연구로 페파민트 오일의 모발 성장 촉진 효과 및 항 비듬균 활성(Oh et al., 2014), 녹차 씨 오일이 염색 및 탈색된 모발의 재 손상 및 탈색 방지 에 미치는 영향(Min et al., 2013) 등이 연구되었다. 오일 류의 연구 가 진행되었지만 모발 성장, 두피 상태 변화의 연구가 있었고, 모발 의 손상 개선에 대한 연구는 이루어지고 있지만 미비한 실정이다. 이에 우리가 쉽게 적합 수 있는 땅콩오일을 가지고 모발의 손상 개 선 정도를 알아보고자 하였다. 땅콩 오일은 국내에서는 1969년에 
식품 및 식품 소재로 이용을 위해서 품종개량 연구가 시작되어 다양 한 품종이 개발되고 있다(Lee et al., 2004). 일반적인 땅콩의 지용 성 성분에 대한 구성을 보면 지사이 약 $50 \%$ 차지하며, 그 중 불포화 지방인 올레산(oleic aci)이 전체 지방의 반 이상을 차지하고 있으며, 리놀렌산(linoleic acid)도 높은 비율로 존재한다(Shin, 2017). 또한 비타민이나 미네랄과 같은 유용한 양양 성분들이 많이 포함되어 있 어 식품 용이나 간식용 뿐만 아니라 가공제품 원료로 이용되고 있다 (Park et al., 2017). 선행 연구와 같이 땅콩오일에는 올레산, 리놀 렌산, 비타민, 미네랄을 함유하고 있다. 이러한 땅콩오일 모발 손상 을 개선하는데 효과가 있을 것으로 가정하여 연구를 시작하였다.

따라서 본 연구는 땅콩오일이 모발 개선 원료로 사용 가능 한지 를 알아보고자 하였다. 실험을 위해 땅콩 오일을 함량 별로 다르게 하여 모발 개선제를 제조하였다. 제조된 모발 개선제로 대조군과 실 험군에 도포 후 비교 분석하였다. 비교 분석은 땅콩 오일에 의해 모 발의 색이 변화 하는지를 알아보고자 색차계 측정과 물 빠짐을 측정 하였고, 손상된 모발을 개선하는데 효과가 있는지 알기 위해 인장강 도, 메틸렌블루를 이용한 흡광도 측정, 광택을 측정하여 개선 정도 를 알아보고자 하였다.

\section{Methods}

\section{1. 실험재료}

\section{1) 시료 모발}

실험에 사용된 모발은 최근 2 년 동안 약물복용과 화학적 시술을 하지 않은 18 세 여성의 모발을 후두부에서 두피 $3 \mathrm{~cm}$ 지점을 기준 으로 $20 \mathrm{~cm}$ 로 채취하여 $2 \mathrm{~g}$ 씩 모(hair) 다발을 만들었다. $\mathrm{pH} 7.0$ 의
중성 샴푸로 세척, 자연건조하여 사용하였다. 이후 땅콩 오일의 모 발 손상 개선 정도를 확인하기 위하여 건강모와 건강 모발에 탈색 제 제1제(ammonium persulfate, potassium persulfate, sodium metasilicate, magnesium, sodium carboxymethyl cellulose) (Suanhj, Korea) $3 \mathrm{mg}$ 과 제 2 제(6\%의 과산화수소를 주성분으 로 water, etidronic acid, phosphoric acid, sodium phosphate dibasic, cetyl alcohol로 구성된 제품) (Suanhj, Korea) $3 \mathrm{~mL}$ 비율 로 혼합하여 도포하고 $30 \mathrm{~min}$ 방치 후 세척하여 명도 7레벨 시료 를 제작하였다. 탈색으로 7레벨이 된 시료를 대조군(control group) 으로 하였고, 명도 차에 의한 비교를 위해 한번의 탈색을 더해서 9 레벨의 시료도 제작하였다. 실험에 사용된 모발 시료의 level 측정기 (level scale, Wella, Germany) 사용하였으며 level 측정은 미용 현장 에서 $8 \mathrm{yr}$ 이상 근무한 전문가 3 인이 측정하였다. 측정된 시료를 실 험에 사용하였다. 이 시료에 땅콩오일을 함량 별로 달리하여 제조한 모질 개선제를 도포한 시료를 실험군(experiment group)으로 하였 다.

\section{2) 땅콩오일}

실험에 사용 한 땅콩오일은 원산지가 인도이고 추출 부위는 seed 에서 추출한 오일로 화장품원료로 사용되는 오일(Korea Similac, Walterenterprise Co., Lt, Korea)을 구입하여 사용하였다.
3) 모질 개선제 제조
실험에 사용한 모질 개선제는 (주)수안향장(Korea)에서 제조한 것 으로 모든 실험에서 사용하였으며, 모질 개선제 조성표는 Table 1과 같다. 땅콩오일을 $0 \%, 3 \%, 6 \% 9 \%$ 로 함량을 다르게 하여 제조하였 다.

\section{Table 1. Composition of hair-treatment agent}

\begin{tabular}{|c|c|c|c|}
\hline No & Ingredients & Content (\%) & Function \\
\hline 1 & Water & 82.030000 & Solvent \\
\hline 2 & Cetyl alcohol & 5.672000 & Emulsion stabilizer \\
\hline 3 & Propylene glycol & 2.700000 & Conditioning agent \\
\hline 4 & Cyclopentasiloxane & 2.500000 & Conditioning agent \\
\hline 5 & Stearyl alcohol & 1.840000 & Emulsion stabilizer \\
\hline 6 & Stearamidopropyl dimethylamine & 1.500000 & Antistatic agent \\
\hline 7 & Steartrimonium chloride & 1.300000 & Conditioning agent \\
\hline 8 & Cetrimonium chloride & 0.870000 & Antistatic agent \\
\hline 9 & Behentrimonium chloride & 0.800000 & Antistatic agent \\
\hline 10 & Myristyl alcohol & 0.384000 & Emulsion stabilizer \\
\hline 11 & Isopropyl alcohol & 0.200000 & Solvent \\
\hline 12 & Lauryl alcohol & 0.104000 & Emulsion stabilizer \\
\hline 13 & Disodium EDTA & 0.100000 & Chelating agent \\
\hline
\end{tabular}


4) 측정기기 및 측정방법

(1) 대조군과 실험군의 표면 색상 $\left(\mathrm{L}^{*}, \mathrm{a}^{*}, \mathrm{~b}^{*}, \Delta \mathrm{E}^{*}\right)$ 변화 측정

함량 별로 땅콩오일이 함유된 모발 개선제로 도포한 실험군와 땅 콩오일을 함유 하지 않은 개선제를 도포한 대조군의 표면 색상 변화 를 알아보고자 색차계(Color meter, CS-10; CHN spec, China)를 이용하여 CIELAB 표색계의 색상 값인 명도지수 $\mathrm{L}^{*}$ 과 색 좌표 지수 인 $\mathrm{a}^{*}$ 와 $\mathrm{b}^{*}$ 값을 측정하였다. 이때 광원과 광측 조건은 $\mathrm{D} 65 / 10^{\circ}$ 의 조 건이었다.

$\mathrm{L}^{*}$ : CIELAB 표색계의 white-black축에서의 명도지수

$\mathrm{a}^{*}$ : CIELAB 표색계의 red-green 축에서의 채도지수

$\mathrm{b}^{*}$ : CIELAB 표색계의 yellow-blue 축에서의 채도지수

$\Delta \mathrm{E}^{*}$ : 색의 정도 차이, 절대 색 좌표의 차이

측정값의 신뢰성을 높이기 위해 5 번 측정하여 최고 값과 최저 값 을 제외한 나머지 값의 평균을 구하였다.

\section{(2) 물 빠짐 측정}

땅콩오일로 제조된 개선제의 물 빠짐 정도를 알기 위함이다. 물 빠짐 측정 방법은 탁도계(Turbidity meter, TU-2016; Lutron electronic, Taiwan) 기기를 이용하여 실험군을 측정하였다. 200 $\mathrm{mL}$ 비이커에 정제수를 넣고 시료를 담근 후 탁도를 측정하였다. 측 정 기간은 3 일로 $24 \mathrm{~h}$ 주기로 측정하였다.

물 빠짐 측정을 위해서는 모든 실험군을 사용하지는 않고, 가장 명도가 높은 9 레벨의 실험군으 로 물 빠짐 측정을 하였다.

\section{(3) 인장강도 측정}

모질의 개선 정도를 알기 위해 함량 별로 땅콩오일로 도포한 실 험군과 땅콩오일이 함유되지 않은 개선제로 도포한 대조군의 인장 강도 측정 기기는 (Digital force gauge, HF-20; Tripod, China)로 인장강도를 측정하였다. 측정값의 신뢰성을 위하여 5 회측정 후 측정 값 중 제일 높은 값과 제일 낮은 값을 제외한 남은 측정값의 평균값 을 구하였다.

\section{(4) 메틸렌블루를 이용한 흡광도 측정}

모질의 손상 개선 정도를 알기 위해 함량 별로 땅콩오일을 함유한 개선제로 도포한 실험군과 함유되지 않은 개선제로 도포한 대조군
의 외경은 마이크로미터(Quickmike, Mitutoyo)를 이용하여 0.070$0.075 \mathrm{~m}$ 의 굵기 오차범위를 정하고 $5 \mathrm{~cm}$ 의 길이로 3 가닥 잘랐다. 자른 후 3가닥의 모발을 tube에 넣은 후 MB solution에 담가 vortex mixer (Vortex genie 2, Scientific Industries, USA)를 이용하여 10 $\mathrm{s}$ 동안 vortexing하였다. $50^{\circ} \mathrm{C}$ heat block (wise therm $\mathrm{HB}-48 \mathrm{P}$; Daihan Scientific, Korea)에서 10 min간 유지하여 MB solution 을 흡착시키고, tube에 있는 3 가닥의 시료를 꺼내어 표면에 묻어있 는 MB solution은 실험용 티슈를 이용하여 제거하고, 시료 한 가닥 씩 새 tube에 옮긴다. 다시 tube에 NR desorb solution을 $5 \mathrm{~mL}$ 를 넣고 상온에서 $5 \mathrm{~min}$ 방치 후 $10 \mathrm{~s}$ vortexing 후 추출하였으며, 추 출한 용액을 큐벳(cuvettes)에 $3000 \mu \mathrm{L}$ 분주하여 $\mathrm{MB}$ 의 흡수 강도 가 가장 높은 파장인 $660 \mathrm{~nm}$ 로 흡광도를 측정하였다. 1 회 추출 후 같은 방법으로 총3회 분광광도계(Vis spectrophotometer, SV1200; Azzota, USA)로 흡광도를 측정하고 그 값의 평균을 구하였다. 측정 시 기준 값을 잡기 위해 desorb solution을 $3000 \mu \mathrm{L}$ 분주하여 blank 를 만들어준다. $\mathrm{MB}$ 시약은 $\mathrm{DW} 20 \mathrm{~mL}+\mathrm{MB} 400 \mu \mathrm{L}$ 으로 희석하여 $2 \%$ 로 만들어 사용하였다. NR solution은 $49 \%$ ethanol $(49 \mathrm{~mL})+$ $1 \%$ glacial aceticacid $(1 \mathrm{~mL})+50 \% \mathrm{DW}(50 \mathrm{~mL})$ 의 비율로 완성하 였다.

\section{(5) 모발 표면 광택 측정}

모질의 손상 개선 정도를 알기 위함이다. 함량 별로 땅콩오일을 함유한 개선제로 도포한 실험군과 땅콩오일이 함유되지 않은 개선 제로 도포한 대조군의 광택 변화를 알아보고자 광택계(Gloss meter NHG268; Shenzhen Threenh Technology, China)를 이용하여 측 정하였다. 측정값의 신뢰성을 높이기 위해 5 번 측정하여 최고 값과 최저 값을 제외한 나머지 갑의 평균을 구하였다.

\section{5) 도포 실험방법}

건강모와 탈색 시술한 시료 레벨 7레벨, 9레벨 시료를 제작하였 다. 땅콩오일을 $0 \%, 3 \%, 6 \%, 9 \%$ 함량을 첨가한 모질 개선제를 제조 하여 각각의 시료에 $15 \mathrm{~g}$ 도포하였다. 도포한 후 열처리 $10 \mathrm{~min}$ 과 자연건조 $10 \mathrm{~min}$ 후에 세척하여 자연건조 시켜 측정하였다. 모질 개 선제 도포는 도포량, 자연방치시간, 열처리 시간, 시술자의 숙련도 에 등에 따라서 측정에 차이가 있을 수 있기 때문에 최대한 차이를

Table 2. Samples' dye treatment scheme

\begin{tabular}{ll}
\hline Sample & \multicolumn{1}{c}{ Content } \\
\hline Virgin hair & Undamaged hair \\
Peanut oil 7 level $0 \%$ & Treatment of level-7 sample with peanut oil $0 \%$ dye \\
Peanut oil 7 level 3\% & Treatment of level-7 sample with peanut oil $3 \%$ dye \\
Peanut oil 7 level $6 \%$ & Treatment of level-7 sample with peanut oil $6 \%$ dye \\
Peanut oil 7 level $9 \%$ & Treatment of level-7 sample with peanut oil $9 \%$ dye \\
Peanut oil 9 level $9 \%$ & Treatment of level-9 sample with peanut oil $9 \%$ dye \\
\hline
\end{tabular}


줄이기 위해 시술자는 각 단계별로 동일인이 시술하였다. 각 땅콩오 일의 함량에 따른 시료 표기는 Table 2 와 같다.

\section{Results and Discussion}

\section{1. 땅콩오일 함량에 따른 대조군과 실험군의 표면 색상 변화 측정}

모발 손상을 줄이기 위한 방법으로 천연 염모제의 연구 개발이 꾸 준히 이루어지고 있다. 천연 성분인 땅콩오일 함량을 $0 \%, 3 \%, 6 \%$, $9 \%$ 달리하여 제조한 모질 개선제를 실험군에 도포하여 표면색상 변 화를 측정 한 결과 다음과 같은 결과를 얻을 수 있었다.

1) 실험군의 $L^{*}$ 측정

땅콩오일을 $0 \%, 3 \%, 6 \%, 9 \%$ 함량 별로 제조한 모질 개선제로 도 포한 후 열처리 $10 \mathrm{~min}$ 과 자연방치 $10 \mathrm{~min}$ 후에 모발의 표면 색상 측정 결과 $\mathrm{L}^{*}$ 값은 Table 3 과 같다.

$\mathrm{L}^{*}$ 은 밝기인 명도(lightness)를 표현하는 수치로 0 에서 100 사이의 수치로 표시한다. 이때 0 은 black을 나타내고, 100 은 white를 나타 낸다. 땅콩오일을 함유한 개선제로 도포한 모발의 L'값은 대조군(7 레벨 땅콩오일 $0 \%$ 함유)와 비교하여 각각의 7 레벨에서 $3 \%, 6 \%, 9 \%$ 함유한 실험군의 $\mathrm{L}^{*}$ 값은 감소하는 것을 알 수 있었다. 같은 레벨에서 땅콩오일 함량이 많을수록 L ${ }^{*}$ 값은 감소하는 것을 확인 할 수 있었고 감소폭은 미비하게 나타났다. 미비한 감소 폭은 땅콩오일 함량이 증 가함에 따른 결과로 사료된다. 건강모보다는 실험군의 L"값은 모두 가 큰 차이로 증가하였다.

또한 9 레벨에 $9 \%$ 함유한 실험군에서는 L*값이 대조군 보다 15.52 차이로 증가함을 확인 할 수 있었다. 이 결과는 모발의 레벨이 높을 수록 큰 차이는 아니지만 $\mathrm{L}^{*}$ 값이 증가한 것으로 나타났다. 또한 같 은 땅콩오일 $9 \%$ 함량이지만 7레벨 실험군보다 9레벨 실험군의 값이 18.12 차이로 증가하였다. 이는 탈색이 거듭될수록 저명도에서 중명 도로 이행된다(Kim et al., 2006)는 내용과, 모발 시료의 바탕 레벨 이 높을수록 명도가 높아진다는 $\operatorname{Kim}$ (2018)의 연구결과와 같은 결 과이다.
2) 실험군의 $a^{*}, b^{*}$ 측정

땅콩오일 색소를 함량을 $0 \%, 3 \%, 6 \%, 9 \%$ 달리하여 제조한 모질 개선제로 실험군에 도포하여 모발의 표면 색상 분석 결과 $a^{*}$ 와 $b^{*}$ 값 은 Table 4 와 같다.

땅콩오일분만을 함량 별로 다르게 제조하여 7레벨에 도포한 모발 의 $\mathrm{a}^{*}$ 값은 대조군(7레벨땅콩오일 $0 \%$ 함유)보다 모두 $\mathrm{a}^{*}$ 값이 + 로 미비 하지만 증가 되었다. 그러나 같은 7레벨에서는 땅콩오일 함량이 증가 할수록 $\mathrm{a}$ 값음 미비하지만 감소하는 경향을 보였다. 9 레벨 도포한 모 발의 $\mathrm{a}^{*}$ 값은 대조군 보다 $\mathrm{a}^{*}$ 값이 6.88 차이로 감소 하였다. 이는 9 레 벨의 명도에서 땅콩오일이 모발 표면에 코팅 되는 성질로 $\mathrm{a}$ *인 빨강색 계열이 감소하여 표면 색상 변화를 가져오는 것으로 사료된다.

땅콩오일을 함량 별로 다르게 제조하여 7레벨에 도포한 실험군의 $b^{*}$ 값은 대조군보다 모두 $b^{*}$ 값과 차이가 없음을 알 수 있었다. 그리고 9 레벨 도포한 실험군의 $b^{*}$ 값은 대조군보다 $b^{*}$ 값보다 미비하지만 증 가하였다. 이는 $\mathrm{a}^{*}$ 값의 변화와 반대로 나왔다. 9 레벨의 명도는 황색 계열이 강하게 나타나기 때문에 $\mathrm{a}^{*}$ 값처럼 감소하지 않고 미비하지만 증가 한 것으로 사료된다. 건강모와 비교 시 실험군의 $a^{*}$ 와 $b^{*}$ 값은 모두 증가하였다.

\section{3) 실험군의 $\Delta \mathrm{E}^{*}$ 측정}

$\Delta \mathrm{E}^{*}$ 값은 색의 정도 차이, 절대 색 좌표의 차이를 말한다. 이는 두가지 색의 차이, 방향의 차이는 알 수 없지만 색차를 한가지 수치 로 나타낸 것이다. 땅콩오일 함량을 $0 \%, 3 \%, 6 \%, 9 \%$ 달리하여 제조 한 모질 개선제로 모발 시료에 도포하여 모발의 표면 색상 분석 결과 $\Delta \mathrm{E}^{*}$ 값은 Table 5 와 같다. 땅콩오일을 함량 별로 다르게 제조하여 7 레벨에 도포 시 실험군의 $\Delta \mathrm{E}^{*}$ 값은 대조군(7레벨 땅콩오일 $0 \%$ 함유) 보다 모두 $\Delta \mathrm{E}^{*}$ 값이 미비하지만 증가 되었다. 또한 9 레벨 도포한 실 험군의 $\Delta \mathrm{E}^{*}$ 값은 대조군 보다 $\Delta \mathrm{E}^{*}$ 값이 15.26 증가 되었다. 이는 $\Delta$ $\mathrm{E}^{*}$ 값의 산출에서 $\mathrm{L}^{*}, \mathrm{a}^{*}, \mathrm{~b}^{*}$ 을 동시에 보는 것으로서 7 레벨과 9 레벨 의 명도가 차이의 결과로 사료된다. 이는 염색모와 퍼머모가 시술 중 에 받은 화학 처리로 인하여 $\Delta \mathrm{E}^{*}$ 값이 증가한다(Chang, 2016)는 내 용과 같은 결과로 나타나는 것을 알 수 있었다. 건강모와 비교 시 실 험군 $\Delta \mathrm{E}^{*}$ 값은 모두 증가 하였다.

Table 3. Brightness $L^{*}$ value

\begin{tabular}{lcccccc}
\hline Sample & Virgin hair & 7 level 0\% & 7 level 3\% & 7 level 6\% & 7 level 9\% & 9 level 9\% \\
$\mathrm{L}^{*}$ value & 5.13 & 38.53 & 36.27 & 35.86 & 35.93 & 54.05 \\
\hline
\end{tabular}

Table 4. $a^{*}, b^{*}$ value

\begin{tabular}{lcccccc}
\hline Sample & Virgin hair & 7 level 0\% & 7 level 3\% & 7 level 6\% & 7 level 9\% & 9 level 9\% \\
$\mathrm{a}^{*}$ & 0.34 & 13.56 & 15.57 & 14.78 & 14.31 & 8.68 \\
$\mathrm{~b}^{*}$ & 1.13 & 25.44 & 25.54 & 25.71 & 26.14 & 26.22 \\
\hline
\end{tabular}

Table 5. $\Delta \mathrm{E}^{*}$ value

\begin{tabular}{lcccccc}
\hline Sample & Virgin hair & 7 level 0\% & 7 level 3\% & 7 level 6\% & 7 level 9\% & 9 level 9\% \\
$\Delta \mathrm{E}^{*}$ value & 13.84 & 30.79 & 32.53 & 33.37 & 34.45 & 46.05 \\
\hline
\end{tabular}




\section{2. 실험군의 물 빠짐 측정}

땅콩오일로 도포한 실험군의 물 빠짐 측정 결과는 Table 6 과 같 다. 물 빠짐 측정을 위해서 가장 명도가 높은 9 레벨의 실험군으로 물 빠짐 측정을 하였다. 이는 9 레벨의 모발이 손상이 7레벨보다 손상이 심하기 때문에 제조한 모질 개선제의 물 빠짐이 가장 심할 것으로 판 단하였기 때문이다. 측정결과 1 일차에는 가장 많이 $0.41 \mathrm{NTU}$ 가 빠 졌고 2 일차부터는 더 이상의 물 빠짐이 없었다. 땅콩오일이 거의 무 색에 가까워 색에 의한 물 빠짐은 거의 일어나지 않은 것을 알 수 있 었다. 1 일차에 미비하지만 물 빠짐이 일어난 경우는 모발의 손상으 로 인한 색의 유실(Kim \& Yoo, 2019)의 결과 인 것으로 사료된다.

\section{3. 실험군의 인장강도 측정}

땅콩오일을 함량을 $0 \%, 3 \%, 6 \%, 9 \%$ 달리하여 제조한 모질 개선 제로 실험군에 도포하여 분석한 인장강도 결과는 Table 7과 같다.

인장강도 측정결과 땅콩오일 함량 별 7 레벨의 $3 \%, 6 \%, 9 \%$ 실험 군의 인장강도 변화는 $0 \%$ 함유한 대조군(7레벨 땅콩오일 $0 \%$ 함유) 보다 증가함을 알 수 있었다. 이는 땅콩오일이 모질 개선 효과가 있 는 것으로 사료된다. 또한 땅콩오일 함량이 증가할수록 미비하지만 인장강도 역시 증가하였다. 9레벨의 실험군은 대조군보다 오히려 인장강도가 낮았다. 이는 탈색을 2 번하는 동안 모발의 손상이 더 심 해짐에 따른 결과로 사료된다. 또한 땅콩오일 함량 별 7레벨의 $3 \%$, $6 \%, 9 \%$ 실험모보다도 $12 \%$ 함유한 9 레벨 실험군의 인장강도가 낮았 다. 이는 탈색제에 의해 모표피 내의 세포막복합체 유실과 함께 모피 간충물질 유실로 인장강도가 저하 되는 것과 또한 모발은 화학적으 로 단백질 중의 시스틴 함량이 감소하여 물리적으로 인장강도가 감 소한다(Oh \& Choe, 2012)는 내용과 같은 결과이다. 건강모와 비교 시 실험군의 인장강도는 모두가 낮음을 알 수 있었다. 이는 모발 손 상에 의한 것이다.

\section{4. 실험군의 메틸렌블루를 이용한 흡광도 측정 결과}

땅콩오일로 도포한 실험군의 메틸렌블루의 흡광도 측정결과는 Table 8과 같다.

정확한 측정 결과를 위해 총 3 회 측정값의 평균값을 내었다. 흡광 도 측정 결과 땅콩오일 함량 별 7 레벨의 $3 \%, 6 \%, 9 \%$ 실험군의 흡광 도 변화는 $0 \%$ 함유한 대조군(7레벨 땅콩오일 $0 \%$ 함유)보다 감소함 을 알 수 있었다. 이는 땅콩오일이 손상된 모표피에 흡착, 모피질 내 부의 공동에 흡수된 결과로 사료된다. 이는 모발 손상 방지제 효과 (Lim, 2015)와 인삼추출물이 모발의 손상에 영향을 미치는데 농도 에 따라 흡광도의 증가하는 정도가 줄어든다(Lee \& Ham, 2010)는 결과와 동일한 결과가 나왔다. 이 결과로 땅콩오일이 모질의 개선효 과가 있는 것을 알 수 있었다. 그러나 땅콩오일 $12 \%$ 함유한 7 레벨과 9 레벨의 실험군 흡광도 차이는 9 레벨의 실험군이 0.008 높았다. 이 는 2 번의 탈색으로 모발 손상이 7 레벨보다 심하여 이러한 결과가 나 온 것으로 사료된다. 건강모와 비교 시 실험군의 흡광도는 모두 높음 을 알 수 있었다. 이는 손상된 탈색모에 의한 결과이다.

\section{5. 실험군의 광택 측정 결과}

땅콩오일로 도포한 시료의 광택 측정결과는 Table 9 와 같다. 광택 측정 결과 땅콩오일 함량 별 7 레벨의 $3 \%, 6 \%, 9 \%$ 실험군의 광택 변 화는 $0 \%$ 함유한 대조군(7레벨 땅콩오일 $0 \%$ 함유)보다 증가함을 알 수 있었다. 이는 땅콩오일이 광택 효과가 있기 때문이라 사료되고, 오일이 손상된 모표피에 흡착 되어 광택 상승 효과를 야기 한 것으로 사료된다. 이는 오일, 왁스 겔의 광택도는 오일 함량에 비례한다는 (Choi et al., 2010)의 결과와 같은 것을 알 수 있었다.

그러나 땅콩오일 $9 \%$ 의 9 레벨 실험군은 대조군 보다는 0.40 증가 하였고, 땅콩오일 $9 \%$ 의 7레벨의 실험군 보다 광택이 0.35 높게 나타 났다. 이는 2 번의 탈색으로 모발 시료가 밝은 색으로 변하여 광택에 영향을 준 것으로 사료된다. 이 결과 땅콩오일이 광택에 영향을 미치 는 것을 알 수 있었다. 건강모와 비교 시 실험군의 광택 정도는 모두 높음을 알 수 있었다.

Table 6. Pigment loss

(Unit: NTU)

Sample (9 level 9\%)

Pigment loss value

1 day

0.41

2 day

0 day

Table 7. Tensile strength value

(Unit: kgf/mm²)

\begin{tabular}{lcccccc}
\hline Sample & Virgin hair & 7 level 0\% & 7 level 3\% & 7 level 6\% & 7 level 9\% & 9 level 9\% \\
\hline Tensile strength value & 1.41 & 0.97 & 1.12 & 1.10 & 1.23 & 0.91 \\
\hline
\end{tabular}

Table 8. Optical density value

(Unit: Abs)

\begin{tabular}{lcccccc}
\hline Sample & Virgin hair & 7 level 0\% & 7 level 3\% & 7 level 6\% & 7 level 9\% & 9 level 9\% \\
Optical density value & 0.063 & 0.105 & 0.087 & 0.082 & 0.083 & 0.091 \\
\hline
\end{tabular}

Table 9. Gloss meter value

(Unit: GU)

\begin{tabular}{lcccccc}
\hline Sample & Virgin hair & 7 level 0\% & 7 level 6\% & 7 level 9\% & 7 level 12\% & 9 level 12\% \\
Gloss meter value & 0.40 & 0.90 & 0.95 & 0.94 & 0.95 & 1.30 \\
\hline
\end{tabular}




\section{Conclusion}

본 연구는 화학적인 처리로 인해 손상된 모발을 땅콩오일 성분으 로 손상된 모발에 도포 시 모질 개선 효과가 있는지 알기 위한 연구 이다. 모질 개선 효과를 알 기 위해 땅콩오일을 $0 \%, 3 \%, 6 \%, 9 \%$ 로 함량을 다르게 하여 모질 개선제를 제조하였다, 시료는 대조군, 실 험군 시료에 제조한 모질 개선제를 도포 후 열처리와 자연방치를 각 각 $10 \mathrm{~min}$ 하였다. 방치 한 후 플레인 린스 하여 모발을 자연 건조 하였다. 건조한 실험군 별로 표면 색상 변화를 측정하고자 $\mathrm{L}^{*}, \mathrm{a}^{*}, \mathrm{~b}^{*}$ 값과, $\Delta \mathrm{E}^{*}$ 값과, 물 빠짐 값을 비교 분석하였고, 모질의 개선 정도를 알기 위해 인장강도, 메틸렌블루를 이용한 흡광도, 광태 측정을 하 였다. 그 결과 다음과 같은 결론을 얻었다.

첫째, 표면 색상 변화를 알기 위한 $\mathrm{L}^{*}, \mathrm{a}^{*}, \mathrm{~b}^{*}$ 값 측정 결과로 $\mathrm{L}^{*}$ 값 은 땅콩오일로 도포한 실험군의 $\mathrm{L}^{*}$ 값은 대조군(7레벨 땅콩오일 $0 \%$ 함유)와 비교하여 각각의 7 레벨에서 $3 \%, 6 \%, 9 \%$ 함유한 실험군의 $\mathrm{L}^{\star}$ 값은 감소하는 것을 확인 할 수 있다. 같은 레벨에서 땅콩오일 함 량이 많을수록 L*값은 감소하는 것을 확인 할 수 있었고. 이는 땅콩 오일 함량이 증가함에 따른 결과로 사료된다.

모발의 표면 색상 분석 결과 $a^{*}$ 와 $b^{*}$ 값은 땅콩오일을 함량 별로 다 르게 제조하여 7 레벨에 도포한 실험군의 $\mathrm{a}^{*}$ 값은 대조군 모두 $\mathrm{a}^{*}$ 값이 + 로 미비하지만 증가 되었다. $b^{*}$ 값은 대조군과 실험군 모두 큰 차이 가 없었다. 그리고 9 레벨 도포한 실험군의 $b^{*}$ 값은 대조군 보다 $b^{*}$ 값 이 미비하지만 증가하였다. $\Delta \mathrm{E}^{*}$ 값 측정결과는 땅콩오일을 함량 별 로 다르게 제조하여 7 레벨에 도포 시 실험군의 $\Delta \mathrm{E}^{*}$ 값은 대조군보 다 모두 $\Delta \mathrm{E}^{*}$ 값이 미비하지만 증가 되었다. 또한 9 레벨 도포한 실험 군의 $\Delta \mathrm{E}^{*}$ 값은 대조군 보다 $\Delta \mathrm{E}^{*}$ 값이 15.26 증가 되었다.

둘째, 땅콩오일의 물 빠짐을 알기 위한 측정 결과로는 1 일차에는 가장 많이 $0.41 \mathrm{NTU}$ 가 빠졌고, 2 일차부터는 더 이상의 물 빠짐이 없었다. 땅콩오일이 거의 무색에 가까워 색에 의한 물 빠짐은 거의 일어나지 않은 것을 알 수 있었다.

셋째, 모질의 개선 정도를 알기 위한 인장강도 측정 결과로는 땅 콩오일 함량 별 7 레벨의 $3 \%, 6 \%, 9 \%$ 실험군의 인장강도 변화는 대 조군(7레벨 땅콩오일 $0 \%$ 함유)보다 증가함을 알 수 있었다. 이는 땅 콩오일이 모질 개선 효과가 있는 것을 알 수 있었다.

넷째, 모질의 개선 정도를 알기 위한 메틸렌블루를 이용한 흡광도 측정 결과로는 땅콩오일 함량 별 7 레벨의 $3 \%, 6 \%, 9 \%$ 실험군의 흡 광도 변화는 대조군보다 감소함을 알 수 있었다. 이로서 땅콩오일로 제조한 모질 개선제가 모질의 개선효과가 있는 것을 알 수 있었다.

다섯째, 모질의 개선 정도를 알기 위한 광택 측정 결과로는 땅콩 오일 함량 별 7 레벨의 $3 \%, 6 \%, 9 \%$ 실험군의 광택 변화는 대조군 7 레벨 땅콩오일 $0 \%$ 함유)보다 증가함을 알 수 있었다. 이는 땅콩오일 이 광택 효과가 있기 때문이고, 오일이 손상된 모표피에 흡착 되어 광택 상승 효과를 야기 한 것을 알 수 있었다.
이와 같은 결과로 천연 땅콩오일을 함유한 모질 개선제로는 손상 된 모발에 모질의 개선효과가 있는지 연구한 결과 모질 개선 효과가 있는 것을 알 수 있었다. 모발 개선제로 오일에 대한 연구가 이루어 지고 있지만 다양한 경우에 대한 연구는 미비한 실정이다. 차후 연 구 시에는 예를 들어 물 빠짐에 따른 성분의 개선 효과 및 지속성 등 다양한 상황, 경우를 연구 방법에 접목 시켜 실질적으로 모질 개선 효과가 있는지를 연구할 필요가 있다고 생각한다.

\section{Author's contribution}

JK designed all experimental investigations, collected data and wrote the manuscript.

\section{Author details}

Jusub Kim (Professor), Department of Beauty Design, Sangji University, 84 Sangjidae-gil, Wonju-si, Gangwondo 26339, Korea.

\section{References}

Chang MH. Research on the change of hair by an ultraviolet A. Journal of The Korean Society Design Culture. 22: 561568, 2016.

Choi JS, Jin BS. Hair protection effects of hair conditioner containing shea butter. Journal of the Korean Society Design Culture, 25: 593-605, 2019.

Choi KH, Son HH, Lee SM. The effect of glossiness and lattice structure of wax matrixes on using n-parrafin and branched wax. Journal of the Society of Cosmetic Scientists of Korea, 36: 99-103, 2010.

$\mathrm{Ji} \mathrm{JH}$. Effect of Dendropanax morbifera leaf extract treatment on permanent hair waving. Journal of Investigative Cosmetology, 11: 207-213, 2015.

Kim JS. Hair coloring. Kuhminsa, Seoul, p44-45, 2017.

Kim JS, Yoo SE, Kim YJ. Permanent wave. Kuhminsa, Seoul, p59-60, 2013.

Kim JS, Yoo SE. Natural dyeing materials from Opuntia humifusa for hair. Asian Journal of Beauty and Cosmetology, 63: 129-138, 2019.

Kim JS. Comparison of hair damage caused by synthetic hair dyes. Journal of the Korean Society of Cosmetology, 12: 67-73, 2006.

Kim JS. Coloring power and changes in hair quality from 
natural pigment from red paprika. Asian Journal of Beauty and Cosmetology, 61: 369-379, 2018.

Kim JS, Shin HC, Kim KH. Hair cosmetics materials. Kuhminsa, Seoul, p163-164, 2017.

Kim KS, Jeon DW, Ha BJ. Studies on the surface color and tensile property of hair according to bleaching treatment. Fashion Business, 10: 94-105, 2006.

Kim YS, Baek DJ. An effect of hair treatment with the liquid extracted from sweet flags. Journal of Investigative Cosmetology, 4: 171-176, 2008.

Lee SE, Park CH, Bang JK, Seong NS, Chung TY. Comparison on antioxidant potential of several peanut varieties. Journal of the Korean Society of Food and Science and Nutrition, 33: 941-945, 2004.

Lee HN, Ham MY. Hair damage rates and morphological changes from application of a reducing agent prescribing ginseng extract. Asian Journal of Beauty and Cosmetology, 8: 211-224, 2010.

Lim DJ. 3-Step hair dye to hair damage effects. Asian Journal of Beauty and Cosmetology, 50: 743-749, 2015.

Min MJ, Choi MH, Kim GC, Shin HJ. Damage prevention effect of green tea seed oil on colored and decolored hair.
Korean Society for Biotechnology and Bioengineering Journal, 28: 287-294, 2013.

Oh JY, Kim YC, Lee BS. Hair growth promotion effect and anti-bacterial activity against pityrosporum ovale of peppermint oil. Journal of Investigative Cosmetology, 10: 261-269, 2014.

Oh MS, Choe TB. Determination of hair damage index using methylene blue staining method. Journal of the Korean Society of Cosmetology, 18: 531-537, 2012.

Park BH, Lee JH, Kim SH, Cho HS. Oxidative stability of peanut (Arachis hypogaea L.) oil and quality characteristics of the roasted peanuts. Journal of the Korean Society of Food Culture, 32: 128-134, 2017.

Park KH, Lim SN. A study of effects of fermented green tea extract-based treatment on hair. Textile Coloration and Finishing, 26: 353-362, 2014.

Park UK, Lee YM, Lee MH. A study on the hair surface damages for Reynoutria elliptica extract hair dye and traditional hair dye. Journal of the Korea Beauty Design Society, 7: 225-235, 2011.

Shin EC. Nutritional and functional components in peanut oils. Food Industry and Nutrition, 22: 25-28, 2017. 


\section{국문초록}

\section{땅공오일의 모질 개선효과 연구}

김주섭

상지대학교 뷰티디자인학과, 강원도 원주시, 한국

목적: 본 연구는 땅콩오일로 모질 개선제를 제조하여 손상된 모발에 도포하여 모질 개선 효과가 있는 지를 알아보고자 하였다. 방 법: 땅콩오일 함량을 $0 \%, 6 \%, 9 \%, 12 \%$ 로 다르게 하여 모질 개선제를 제조하였다. 제조한 개선제로 탈색한 시료 모발에 도포 후 열 처리와 자연방치를 한 후에 실험군과 대조군을 측정하여 비교 분석하였다. 표면 색상 변화를 알기 위해 색차계를 이용하여 $\mathrm{L}^{*}, \mathrm{a}^{*}$, $\mathrm{b}^{*}, \Delta \mathrm{E}^{*}$ 값과 물 빠짐 정도를 측정하였다. 또한 모질 개선 효과를 알기 위해 인장강도, 메틸렌블루를 이용한 흡광도, 광택을 측정하 였다. 결과: $\mathrm{L}^{*}, \mathrm{a}^{*}, \mathrm{~b}^{*}, \Delta \mathrm{E}^{*}$ 측정 결과는 7레벨의 실험군 $\mathrm{L}^{*}$ 값은 땅콩오일 함량이 증가할수록 감소함을 알 수 있었다. $\mathrm{a}^{*}$ 값은 미비 하지만 증가하였고, $b^{*}$ 값은 차이가 없었다. $\Delta \mathrm{E}^{*}$ 값은 대조군 보다 미비하지만 증가하였다. 물 빠짐 측정 결과는 9 레벨의 실험군이 2 일차에 물 빠짐이 없었다. 인장강도 측정결과는 7 레벨에서는 실험군이 대조군 보다 증가하였다. 메틸렌블루를 이용한 흡광도 분 석결과 7레벨에서 실험군이 대조군 보다 감소하였다. 광택 측정결과는 7레벨에서 실험군이 대조군 보다 증가하였다. 결론: 땅콩오 일이 손상된 모발에 모질 개선 효과가 있는 것을 알 수 있었다. 차후 다양한 방법으로 모질 개선 효과를 측정 연구가 필요하다고 생 각한다.

핵심어: 땅콩오일, 모발, 개선, 모질, 손상

\section{참고문헌}

김경선, 전동원, 하병조. 모발(毛髮)의 탈색정도(脫色程度)에 따른 인장특성(引長特性)과 표면색 변화 연구(表面色 變化 研 究). 패션비즈니스, 10: 94-105, 2006.

김영숙, 백대진. 창포 추출물을 이용한 모발의 트리트먼트 효과. 대한미용학회지, 4: 171-176, 2008.

김주섭. 헤어컬러링. 구민사, 서울, p44-45, 2017.

김주섭, 유세은, 김유정. 퍼머넌트웨이브. 구민사, 서울, p59-60, 2013.

김주섭. 합성염모제에 의한 모살 손상 비교. 한국미용학회지, $12: 67-73,2006$.

김주섭, 신홍철, 김건희. 모발 화장품 성분학. 구민사, 서울, $\mathrm{p} 163-164,2017$.

김주섭, 유세은. 백련초의 모발에 대한 천연염색 원료 연구. 아시안뷰티화장품학술지, 63: 129-138, 2019.

김주섭. 천연 적색 파프리카 색소에 의한 모발 염색력과 모질의 변화. 아시안뷰티화장품학술지, 61: 369-379, 2018.

민명자, 최문희, 김귀철, 신현재. 녹차씨 오일이 염색 및 탈색된 모발의 재손상 및 탈색 방지에 미치는 영향. 한국생물공학

회지, 28: 287-294, 2013.

박귀희, 임순녀. 발효녹차액을 이용한 모발의 트리트먼트 효과. 한국염색가공학회지, 26: 353-362, 2014.

박복희. 김선희. 이정희, 조희숙. 볶음땅콩의 품질특성과 땅콩기름의 산화안정성. 한국식생활문화학회지, $32: 128-134$, 2017.

박유경, 이유미, 이민호. 호장근추출물 염모제와 일반 염모제의 모표피 손상도에 관한 연구. 코리아뷰티디자인학회지, 7 : 225-235, 2011.

신의철. 땅콩기름에 존재하는 영양 및 기능성 성분 고찰. 식품산업과 영양, 22: 25-28, 2017.

이승은, 박장환, 방진기, 성낙술, 정태영. 땅콩 품종간 항산화 활성 비교. 한국식품영양과학회지, 33: 941-945, 2004.

이하나, 함미영. 인삼추출물을 처방한 환원제 적용에 따른 모발 손상도 및 형태학적 변화. 아시안뷰티화장품학술지, 8:

211-224, 2010. 
임대진. 3제형 산화 염모제가 모발 손상에 미치는 영향. 아시안뷰티화장품학술지, 50: 743-749, 2015.

오명숙, 최태부. Methylene Blue 염색법을 이용한 모발 손상지수의 결정. 한국미용학회지, 18: 531-537, 2012.

오지영, 김영철, 이복순. 페파민트 오일의 모발성장 촉진효과 및 항비듬균 활성. 대한미용학회지, 10: 261-269, 2014. 장미화. 자외선 A에 의한 모발 성질의 변화에 관한 연구. 한국디자인문화학회지, 22: 561-568, 2016.

지정훈. 퍼머넌트 웨이브 시술시 황칠나무 잎 트리트먼트가 모발에 미치는 영향. 대한미용학회지, 11: 207-213, 2015. 최기환, 손홍하, 이상민. 직쇄 파라핀 왁스와 분자 왁스 사용에 따른 오일-왁스 켈에 미치는 왁스구조와 광택에 미치는 영 향 연구. 대한화장품학회지, 36: 99-103, 2010.

최중석, 진병석. 시어버터를 이용한 헤어트리트먼트의 모발보호 효과에 관한 연구. 한국디자인문화학회지, 25: 593-605, 2019. 


\section{中文摘要}

\section{花生油对改善发质的功效}

金周䛓

尚志大学美容学科, 江原道原州市, 韩国

目的: 制造具有花生油的头发质地改善剂, 并将其施加到受损的头发上, 探索花生油对改善头发质地的作用。方 法: 在0\%，6\%，9\%和12\%的不同浓度的花生油中生产头发质地改善剂。然后将其施加到漂白的样品头发上， 加热, 并使其保持自然状态。为了量化表面颜色的变化, 使用色差标度测量 $\mathrm{L}^{*}, \mathrm{a}^{*}, \mathrm{~b}^{*}$ 和 $\Delta \mathrm{E}$ *的值以及褪色程 度。另外, 通过使用抗张强度和亚甲基蓝测量染料的吸收率和光泽来检查对头发质地的影响。结果: 随着花生油 含量的增加, 实验组第7级的 $\mathrm{L}^{*}$ 值降低。 $\mathrm{a}^{*}$ 和 $\mathrm{b}^{*}$ 值的变化不明显。 $\Delta \mathrm{E}^{*}$ 值的增加也不显着。螁色结果显示, 第9级 的实验组在第二天没有褪色。与对照组相比, 在第7级中它的抗张强度也提高了。此外, 与对照组相比, 实验组 显示出在第7级上吸收亚甲基蓝的减少。光泽测量结果, 实验组高于对照组。结论: 花生油对改善受损发质有显 著作用。并且需要使用各种方法测量花生油对头发质地的影响的进一步研究。

关键词: 花生油, 头发, 改善, 头发质地, 伤害 